\title{
BOEKE ONTVANG
}

Pieter de Klerk, BLYWENDE KOLONISASIE?, Wetenskaplike Bydraes van die P U vir C H O, Reeks A Geesteswetenskappe, nr 15 P U vir C H O 1975. Prys R4,75.

'n Helder en vloeiend geskrewe bydrae waarin die metode van geskiedenisvergelyking duidelik geillustreer word. By die probleemstelling word die begrip "blywende kolonisasie" toegepas op sulke gevalle in die ge skiedenis "waar dit duidelik is dat die koloniserende... kultuur in alle of die meeste aspekte domineer", of waar albei kulture 'n rol gespeel het in die totstandkoming van die eindkultuur. In die tweede deel van die werk word ' $n$ aantal gevalle van kolonisasie in die geskiedenis ondersoek en duidelik aangetoon in watter gevalle en om welke redes die kolonisasie blywend, of nie blywend was nie. Gevalle wat hier ondersoek word, is byvoorbeeld die Hebreërs in Palestina, die Grieke in Indië, die Arabiere in Spanje, die Britte in sentrale Noord-Amerika en die Britte in Kenia. Die gevolgtrekkings wat hieruit gemaak word, word dan in die derde deel van die werk toegepas op ' $n$ aantal situasies in die moderne tyd, naamlik Ierland, Paraguay, Angola en Mosambiek, SuidAfrika, Rhodesië, Wes-Turkestan en Palestina (Israel). Hoewel die skrywer nêrens pretendeer dat hierdir vergelykingsmetode gebruik kan word om toekomsvoorspellings te maak nie, kom die vraag in verband met die werklike gebruikswaarde van die metode tog sterk by die leser na vore. Elke historiese geval is so gebonde aan inviduele omstandighede en elke prognose is aan soveel voorwaardes onderhewig, dat die gebruikswaarde van die metode in sy toepassing op huidige situasies sterk gerelativeer word, en dit eerder lyk of die waarde van die metode lê by verheldering van historiese situasies - waarin hierdie werk inderdaad ook uitmunt.

D H Steenberg, SESTIGERPROBLEMATIEK, Wetenskaplike bydraes van die $\mathrm{P} \mathrm{U}$ vir $\mathrm{C} \mathrm{H} \mathrm{O}$, Reeks A Geesteswetenskappe, nr 20, P U vir C H O 1975.

Die skrywer beoog met hierdie werk om "na 'n noukeurige omskrywing van die uitdaging wat die literêre situasie rondom Sestig bied, te kom tot die formulering van ' $n$ literatuurbeskouing en norme wat esteties geldig en vir die Christen aanvaarbaar is, en om die uiteindelik prakties op die proef te stel." Nadat die skrywer in die eerste paar paragrawe aanwys uit watter situasie die sestigers na vore gekom het, laat hy in die vierde paragraaf die sestigers self breed aan die woord oor hulle mens- en werklikheidsiening, hulle siening van hulle eie skrywerstaak, die medium wat hulle gebruik, en ten slotte die soveel besproke "littérature engagée". Dan volg 'n bespreking van die polemiek teen die Sestigers, en daarna word die teoretiese benadering van drie verteenwoordigers onder die Sestigers, naamlik Leroux, Brink en Berta Smit van naderby bekyk. Hierteenoor word die standpunte van 'n aantal Christen-literatore gestel, naamlik G Dekker, J L Steyn, Elize Botha en P D van der Walt. In die tweede deel van sy studie gee die skrywer sy "riglyne vir 'n Christelike transformasionele literatuurbeskouing", wat hy in die 
derde deel toepas op "Een vir Azazel" van Leroux. In sy Besluit sien die skrywer die taak van Christen-kritikus so dat hy "met . . . volle inagneming van die intensie. . . van die skrywer - maar sonder tersydestelling van sy eie religieuse norme, die hele roman as getransformeerde visionere proses (moet) vertolk en uiteindelik (moet beoordeel)".

\section{Prof B Duvenage, CALVYN EN DIE EKUMENIESE}

ROEPING VAN DIE KERK, Wetenskaplike Bydraes van die P U vir C H O, Reeks F Instituut vir die Bevordering van Calvinisme. P U vir C H O 1975.

'n Kort samevatting van die inhoud en 'n evaluering van "die geskrifte van outeurs wat hulle met Calvyn en die Ekumene besiggehou het."

Dr C J H Venter, CALVYN EN DIE HERDERLIKE BEDIENING, Wetenskaplike Bydraes van die $\mathrm{P}$ U vir $\mathrm{C} \mathrm{H} \mathrm{O}$, Reeks F Instituut vir die Bevordering van Calvinisme (F4 nr 5). P U vir C H O.

By hierdie bespreking en evaluering van werke oor Calyvn en die herderlike bediening is ook werke oor byvoorbeeld die kerklike tug ingesluit.

\section{P J J S Potgieter, L J DU PLESSIS AS DENKER OOR}

STAAT EN POLITIEK, Wetenskaplike Bydraes van die P U vir C H O, Reeks F Instituut vir die Bevordering van Calvinisme (F5 nr 2). P U vir C H O 1976. Prys R3,50.

Hierdie welkome bydrae oor die denke van L J du Plessis is hoofsaaklik beskrywend van aard. Dit bespreek die agtergrondsfaktore van Du Plessis se staatkundige denke, sy beskouinge in verband met basiese probleme van die Staatsfilosofie, en spesifieke vraagstukke wat in sy tyd en omstandighede belangrik was, en dit sluit af met 'n toespitsing van sy beskouinge op die Suid-Afrikaanse omstandighede. Die hooftrekke van sy staatkundige denke word gesoek in sy Calvinisme en sy Afrikaans-nasionale beskouinge.

Prof dr W P Robertse, Prof dr P H Stoker, Mnr W J Voordewind, Prof dr F J Potgieter, Prof dr D P Erasmus, DIE ENERGIEKRISIS IN SUID-AFRIKA, Wetenskaplike Bydraes van die $\mathrm{P} U$ vir $\mathrm{C} \mathrm{H} \mathrm{O}$, Reeks $\mathrm{F}$ Instituut vir die Bevordering van Calvinisme, $\mathrm{P}$ U vir C H O 1975. Prys R1,50.

Die vyf artikels wat in hierdie werkie saamgevat is, behandel 'n prinsipiële orientering oor tegniek en die energiekrisis; die fiesieschemiese, en die geografiese herkoms van energie; 'n nasionale energiebeleid vir Suid-Afrika, en die belangrikste ekonomiese implikasies van die oliekrisis. 
D J W Strümpfer, MENSE IN RAMPE: INDIVIDUELE EN SOSIALE REAKSIES, Navorsingspublikasie C8, Universiteit van Port Elizabeth 1975. Prys R4,00.

Hierdie boek, wat inligting verskaf oor mense se reaksies op rampe, is bedoel vir die intelligente gewone leser, die leser met belang by burgerlike beskerming - maar sonder sosiaalwetenskaplike opleiding - en studente in die Sosiale Wetenskappe." Dit is seer sekerlik ' $n$ welkome en tydige bydrae wat in die huidige groeiende bewustheid van natuur- en ander rampe van groot nut is.

\section{J A Heese, G S Nienaber en C Pama, FAMILIES, FAMILIE-} NAME EN FAMILIEWAPENS, Die Afrikaner en sy kultuur, deel IV. Tafelberg-Uitwegers 1975. Prys 15,00.

In die eerste deel van hierdie belangrike werk bespreek dr Pama allerlei oor familiewapens en heraldiese simbole, naamlik die geskiedenis van die heraldiek tot in Suid-Afrika, ontwerp en registrasie van 'n familiewapen en die openbare heraldiek. Dr Heese behandel in die tweede deel die Genealogie, die geskiedenis, die bronne, die metodes en die waarde daarvan. Die derde deel, deur prof Nienaber, handel oor Afrikaanse familiename, afgesluit met 'n handige register van familiename. Hierdie is geen volledige opgawe van Afrikaanse familiename nie, maar vir wie meer wil weet oor die heraldiek, familiewapens, die ontstaan en betekenis van familiename, is hierdie werk 'n sine qua non, en daarom 'n welkome toevoeging Afrikaans.

Jan Swanepoel MY DROME BRAND SO MOOI Gedigte 1971 - 1975. Tafelberg-uitgewers Prys R4,25

Agter die poësie in hierdie bundel lê 'n erfenis van D. J. Opperman, Breyten Breytenbach en die surrealiste, en in die verskiet N. P. van Wyk Louw, Dit is duidelik merkbaar, maar dan dra die verse, veral weens die dissipline wat daarin geopenbaar word, so 'n eie stempel dat dit wil-wil langs ander bundels van jonger digters soos Leon Strydom se Geleentheidsverse en Antjie Krog se Januarie-suite kom staan.

Uit die besonder ryp gedigte waarin oor die digterskap besin word, spreek reeds enkele kenmerkende eienskappe van hierdie verse. In $D e$ dighter als slet word gewag gemaak van die spreker se vereenselwiging "met die armes van gees"., 'n subtiele strewe om verstaan te word, van die eie woordkarigheid en 'n vrees vir ontmaskering in die vers. Dit klop met die "klein vergeefse koestering van "sy mense" en die terugkeer na die aarde ná die verkenning van hemel en oseaan in die gedig Icarus, vandaar die verwysing na Gorter se $\mathrm{Mei}$ in Vir jou net vir jou: "gaat gij niet te ver?" Dit is 'n aanduiding van die digter se voorneme van "jy moet die wêreld liefhê soos jouself"' (Die gebreekte ruit). Maar tog spruit hieruit ' $n$ besondere bewussyn van die ewigheid en vlugtigheid 
van die hede, soos in Die onveranderlikes en Sandvaring. In Omegapunt en $U$ het gekom hang dit saam met 'n duidelike Godgerigtheid. Hierdie spanning tussen onmiddellikheid en ewigheid wat merkbaar is, gee aan die gedigte die karakter van pogings om met die woord 'n greep te kry op die vlugtige of telkens 'n sluier te lig oor 'n klein enklave van die waarheid. Nero, Penthesileia en Fragmente van 'n aand vertoon na my mening verskeie aspekte van hierdie werkwyse, wat besonder eg aandoen, omdat hierdie flardes waarheid binne 'n raamwerk geplaas word wat wyer is as wat dikwels in ons jonger poësie aangetref word.

'n Motief wat deurgevoer word in die werkwyse van die digter, is die gebrokenheid van die werklikheid, 'n "sterkind" in ontbinding, 'n "gebreekte ruit", soos blyk uit die afdeling met dié titel. Dit is dan die digter se moeitevolle taak om alles nuut her saam te stel tot die doodgewone (Lens). Dit doen Swanepoel in die geleentheidsportrette soos Icarus, Nero, Hendrik Marsman, Brandende man, Salomé modern en kort onthulligs soos in die elegie in briefvorm en Fragmente van 'n aand, wat daaraan verwant is. Laasgenoemde herinner sterk aan haikuverse, wat goed by vingeroefeninge soos hierdie sou aanpas.

Die titelmotief van die woord as suiwerende wapen en vrug - "'n rooi (brandende) granaat" - en skuiling word in agt tot tien gedigte goed deurgekomponeer in 'n rustig maar deeglik gedissiplineerde loslitstyl. Selfs in betrokke gedigte soos in die afdeling van Die bitter reg, word 'n die steunpunt van die "logge hamer van ou afrika" gevind in die rustige staan van die "suidland van skelet" te midde van storms.

Hierdie bundel is aanduiding van 'n rustige stem wat onder die jonger digters opgaan. Hier is iemand wat die klanke van sy tyd wel in hom opgeneem het maar tog 'n eie stem het en daarin slaag om die waarhede wat hy in die alledaagse vind, te orden met die bindmiddele van die alledaagse woord. Toegegee dat die motiewe in die bundel soms nie klop nie, soos die "bekende stiltes" van die dood in "Vreemde ontmoeting ...." en die volkomendheid van die stilte en die "rustig word van my wêreld" (Uit die ark) en dat die bundel 'n sekere gebrek aan verdiepende spanning het. Tog gee dit onmiskenbaar blyke van 'n digterlike 'arsenaal' waaruit nog meer verwag kan word.

\section{H Steenberg}

